\title{
NUCLEAR AND CYTOPLASMIC INHERITANCE OF RESIST- ANCE TO INFECTION BY NODULE BACTERIA IN RED CLOVER
}

\author{
By P. S. NUTMAN
}

Soil Microbiology Department, Rothamsted Experimental Station, Harpenden, Herts.

\section{CONTENTS}

Received I9.xi. 48

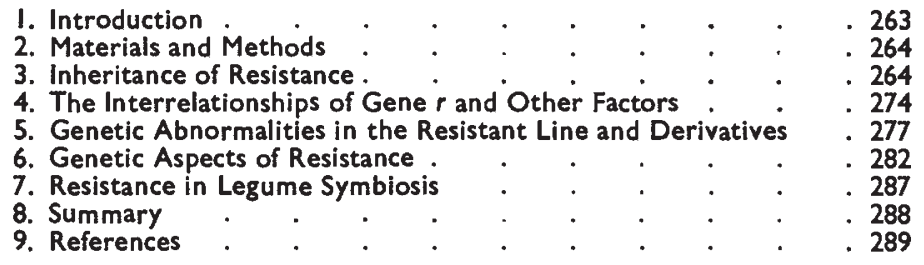

\section{INTRODUCTION}

NoDUle formation in the Leguminosæ is of practically universal occurrence. Of some 12,000 known species of legume only a few species in the Cæsalpinioideæ and Mimosoideæ groups appear to form no nodules, and palæntological evidence (McMillan, 1892, and Sargent, 1892, quoted by Fred, Baldwin and McCoy, 1932) suggests that the absence of nodules in these few exceptional species is the survival of a primitive condition. Outside the Leguminosæ nodules which contain actinomycetes occur on Alnus, and bacterial root nodules on certain Zygophyllaceæ (Sabet, 1946). Otherwise with a few doubtful exceptions the whole of the plant kingdom is devoid of root nodules. Mycorrhizal associations on the other hand are everywhere common - as they also are among legumes.

Within the Leguminosæ conditions of partial resistance occur : all strains of nodule bacteria have become specialised to form nodules on a limited number of species of host plant. So far about 20 groups of strains of Rhizobium, some recognised as species by some authors (Fred, Baldwin and McCoy, 1932), have been distinguished depending upon the range of host plant species each is able to infect. This cross-inoculation group specificity is not rigidly defined (Wilson, 1939; Kleczkowska, Nutman and Bond, 1944), and the groups are principally a convenient way of classifying strains. The exceptions to this classification most frequently occur, however, among groups like the pea and clover groups of bacteria which are antigenically related (Kleczkowski and Thornton, 1944).

There are thus two forms of resistance already known in nature ; viz. (i) the total resistance of Cassia spp., etc., to infection by all nodule 
bacteria, and (ii) the resistance shown by plants of one cross-inoculation group to infection by bacteria isolated from other such groups. Further, failure in nodule formation can also arise by mutation of the bacteria to an avirulent form; clearly, however, this does not involve the plant response and is not a resistance phenomenon.

A preliminary note on the discovery in red clover of an hereditary resistance to infection by its own strain of nodule bacteria was published in 1946 and in the present paper the complete results are presented.

\section{MATERIALS AND METHODS}

The original material was obtained from a commercial sample of Montgomeryshire late-flowering red clover (a diploid species) and all subsequent work was done within this variety with the exception of the original open pollination which was to material of unknown origin.

The plants were grown under standardised conditions which enabled bacteriological control to be maintained. The details have been described elsewhere (Thornton, 1930), the method consisting essentially of the culture of individual plants in test tubes $\left(6^{\prime \prime} \times \frac{3^{\prime \prime}}{4}\right)$ on slopes of previously sterilised agar medium which contains mineral salts but lacks combined nitrogen.

This method although unnecessarily complicated for the study of resistance per se, was used in order to determine the response of nodulating plants in segregating families. After a period of 3-4 months growth selected plants were potted into soil and were hand pollinated using Williams' method (Williams, i 925 ).

Hand harvesting resulted in a high proportion of "hard" seed. Softening of the seed coat and surface sterilisation was done in one operation. This consisted of submersion in concentrated sulphuric acid for 30 minutes followed by from six to ten washes in sterile water. This method for seed sterilisation has proved to be more satisfactory than any of the others more usuaily employed. No injury such as frequently happens with mercuric chloride, even when used without pretreatment, follows this method. Imbibition is uniform and immediate, and germination rapid; the radicle emerging within about 6 hours of treatment.

Degrees of hardness varies individually; half an hour's treatment completely eliminates hardness in all but a few families and is not long enough to damage the material ; damage follows from I-3 hours' treatment. (This method has been found to be applicable to lucerne, vetch, lupin and radish but not to lettuce, barley or spruce.)

\section{INHERITANCE OF RESISTANCE}

(a) Source of material and original crosses

The original resistant plant proved to be wholly resistant to infection by the infective strain $\mathrm{A}$, and also to a collection of other 
strains inoculated at a later stage, and to casual contamination occurring after the plant had been transferred to fresh soil. The phenotypic character was equally definite in derived resistant plants.

The original resistant plant after open-pollination gave resistant and susceptible progeny (abbreviated in tables and figures as res and sus). The resistant plants were chlorotic and capable of only feeble growth, few surviving to maturity.

These resistant plants (indicated in tables $\mathrm{I}$ and 2 as $\mathrm{F}_{1}$ res) were crossed with susceptible sisters and half-sisters and also with unrelated susceptible plants, with the results shown in table $\mathrm{I}$.

TABLE I

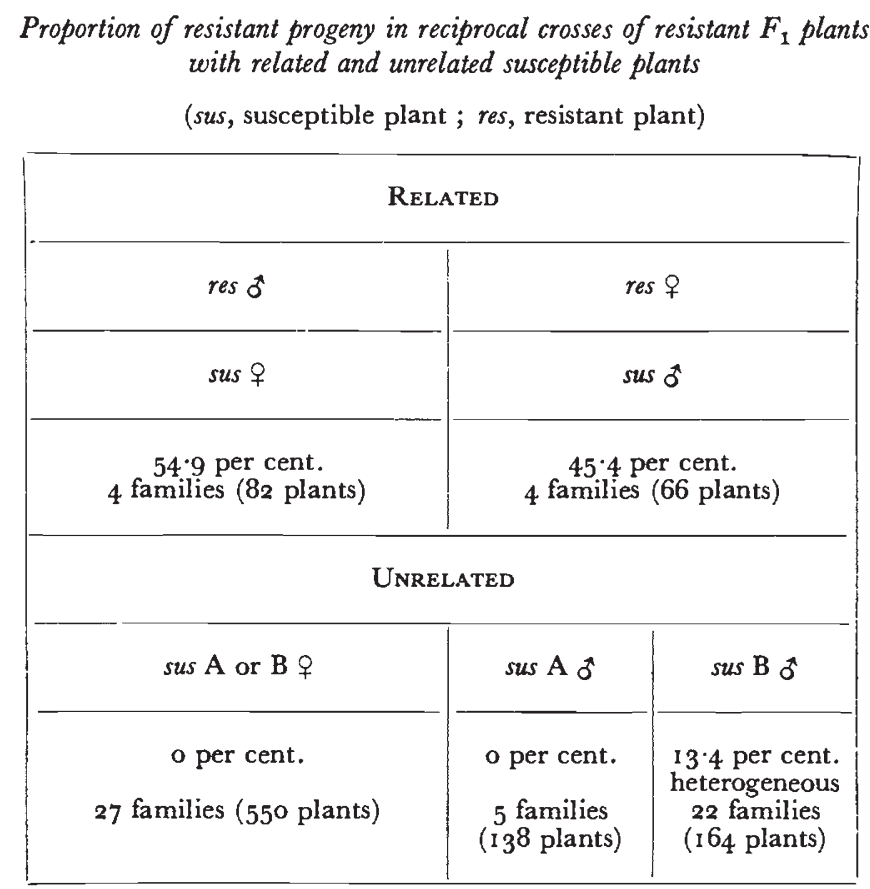

The crosses of related susceptibles with resistants gave equal numbers of resistant and susceptible progeny in families which were homogeneous and showed no reciprocal differences. The unrelated susceptibles were of two kinds $A$ and $B$, sus $A$ giving no resistant progeny and sus $B$ giving a proportion of resistant progeny but only in the cross in which the resistant plant functioned as the $q$ parent. There is thus, it seems, a total elimination of resistants in the crosses of unrelated sus $B \stackrel{q}{ } \times$ res $\delta$ and a partial elimination in the reciprocal cross.

These results suggest that resistance depends on a Mendelian recessive and also on an agent transmitted more effectively through the $q$ parent; the effect of this agent giving heterogeneous results in the mixed class. 
This interpretation was confirmed by the results shown in table 2 . Susceptible progeny of any cross listed in table I when intercrossed

TABLE 2

Proportion of resistant plants in crosses involving the parents and progeny of families listed in table I

\begin{tabular}{|c|c|c|c|c|}
\hline Family no. & Cross & sus & res & $\chi^{2}$ \\
\hline $\begin{array}{l}\ldots(>100) \\
9-15(7) \\
1-4(4) \\
86(1) \\
\ldots\end{array}$ & $\begin{array}{l}\text { UNRELATED sus parent (A or B) inter se } \\
\text { RELATED sus of any origin inter se } \\
\text { RELATED sus of any origin } \times \text { res parent } \\
\text { res parent inter se } \\
\text { res progeny of sus } \mathrm{B} \times \text { res } \mathrm{F}_{1}+{ }^{\circ}\end{array}$ & $\begin{array}{r}>1000 \\
325 \\
73 \\
0\end{array}$ & $\begin{array}{c}0 \\
111 \\
75 \\
19 \\
\text { no mate }\end{array}$ & 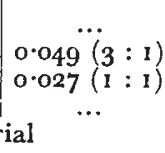 \\
\hline
\end{tabular}

gave 25 per cent. resistants and when backcrossed to resistant parents gave 50 per cent. resistants. The single cross between the two resistant parent plants bred true for resistance and the unrelated susceptible Jarents bred true for susceptibility; see also text-fig. I, page 283 .

The resistant progeny of the sus $B \times$ res $\mathrm{F}_{1}$ ㅇ (table I) were very feeble and could not be bred from, so that the resistant line had to be revived by again crossing to unrelated susceptibles: this will be distinguished as "outcrossing" in the following discussion. Outcrossing is also required by the incompatability relationships in red clover. The recessive resistance factor revealed in these preliminary crosses will be designated $r$.

The interaction between the gene and the maternally inherited component of resistance will be discussed after further evidence for the existence of this gene, and for the maternal inheritance have been separately considered.

\section{(b) The gene $r$}

The preliminary crosses showed that the original outcrosses were of two kinds ; between the original resistant plant $r r$ and homozygous $R R$ plants, and between the original resistant plant and heterozygous $R r$ plants.

It is not legitimate, therefore, to refer to the descendant families of the original resistant plant by filial generation number. Instead, in table 3 which shows the segregation of the gene $r$ in a large number of families of very diverse origin, the crosses are simply classified by parental and grandparental phenotypes. Thus families numbered I to 8 , and $4 \mathrm{I}$ and 42 consist of crosses between susceptible and resistant plants and the remainder of crosses among susceptible types; and in families $\mathrm{I}$ to 8 and 9 to 40 resistant plants occur as immediate ancestors of the susceptible parents of the crosses listed, and in the remaining crosses both grandparents, at least on one side, were themselves also susceptible. No differences between reciprocal crosses were observed. 
In the families ( $\mathrm{I}$ to $4 \mathrm{O}$ ) of varied origin falling outside the secondary division in the table; i.e. with at least one resistant grandparent, very good agreement exists between observed and

TABLE 3

The segregation of susceptible and resistant plants among the descendants of the original outcrossed resistant plant

\begin{tabular}{|c|c|c|c|c|c|c|c|c|}
\hline \multirow{3}{*}{$\begin{array}{l}\text { Family } \\
\text { nos. }\end{array}$} & \multirow{3}{*}{$\begin{array}{l}\text { Type of } \\
\text { cross }\end{array}$} & \multirow{3}{*}{$\begin{array}{l}\text { Phenotypes of } \\
\text { grandparents }\end{array}$} & \multicolumn{4}{|c|}{ Segregation } & \multirow{3}{*}{$\chi^{2}$} & \multirow{3}{*}{$\mathrm{P}<$} \\
\hline & & & \multicolumn{2}{|c|}{ Observed } & \multicolumn{2}{|c|}{ Expected } & & \\
\hline & & & sus & res & sus & res & & \\
\hline I- 8 (8) & res $\times$ sus & res; res and sus & 103 & 105 & 104 & 104 & 0.019 & $\ldots$ \\
\hline $\begin{array}{ll}4 \mathrm{I} & \text { (I) } \\
4^{2} & \text { (I) }\end{array}$ & ", & $\begin{array}{c}\text { res; sus and sus } \\
\text { ", }\end{array}$ & $\begin{array}{l}50 \\
59\end{array}$ & $\begin{array}{l}2 \\
0\end{array}$ & $\begin{array}{l}26 \\
\cdots\end{array}$ & $\begin{array}{l}26 \\
\cdots\end{array}$ & $\begin{array}{c}44 \cdot 3^{1} \\
\ldots\end{array}$ & $\begin{array}{c}0.01 \\
\ldots\end{array}$ \\
\hline $\begin{array}{ccc}9-37 & (29) \\
38 & \\
39,40 & (2)\end{array}$ & $\begin{array}{c}\text { sus } \times \text { sus } \\
\quad " \\
"\end{array}$ & $\begin{array}{l}\text { both res and sus } \\
\text { res; res and sus } \\
\text { (selfs) res and sus }\end{array}$ & $\begin{array}{r}1075 \\
40 \\
1\end{array}$ & $\begin{array}{r}352 \\
5 \\
\mathrm{I}\end{array}$ & $\begin{array}{c}1070 \cdot 2 \\
33^{\circ} \cdot 8 \\
I\end{array}$ & $\begin{array}{c}356 \cdot 8 \\
I I \cdot 2 \\
I\end{array}$ & $\begin{array}{c}0 \cdot 08 \\
4 \cdot 63 \\
\ldots\end{array}$ & $\begin{array}{c}\ldots \\
0.05 \\
\ldots\end{array}$ \\
\hline $\begin{array}{ll}43-47 & (5) \\
48-54 & (7)\end{array}$ & ", & $\begin{array}{c}\text { res and sus; } \\
\text { sus and sus } \\
\text {," }\end{array}$ & $\begin{array}{l}164 \\
107\end{array}$ & 12 & $13^{2}$ & 44 & $3^{1 \cdot 03}$ & 0.01 \\
\hline $\begin{array}{l}55-63(9) \\
64-85(22)\end{array}$ & ", & both sus and sus & $\begin{array}{l}173 \\
467\end{array}$ & $\begin{array}{r}24 \\
0\end{array}$ & $\begin{array}{l}147 \cdot 8 \\
\ldots\end{array}$ & $\begin{array}{l}49^{\cdot 2} \\
\cdots\end{array}$ & $17 \cdot 26$ & $\begin{array}{c}0.01 \\
\ldots\end{array}$ \\
\hline
\end{tabular}

expected values; in one family only (family 38 ) is there an excess of susceptible plants. The families within each type of cross are, as we shall see, generally homogeneous.

In the remaining families, in which the susceptible parent plants were themselves derived from susceptible plants the families are heterogeneous. The proportion of mixed families ( 15 families in 43) is in accordance with expectation; a closer study of the lineages showed that i4 families should have been mixed. As well as being heterogeneous the proportion of resistant plants in these families departs significantly from the expected values. This discrepancy may be due to (I) linkage with lethal genes, (2) depression of the low vitality of the resistant plant on inbreeding, or (3) the dilution of the cytoplasmic factor of the inheritance.

The last possibility (3) affords a possible explanation if the production of the cytoplasmic material is under the control of the gene $r$. As noted above, one or both grandparents of the susceptible parents of the abnormally segregating families were susceptible so that the line of descent was wholly susceptible for two generations. Under these conditions dilution of the cytoplasmic factor could occur, and with insufficient of this material the homozygous recessives would be eliminated (see table I). The breeding system of red clover makes 
the detection of zygotic lethals uncertain and little difference was noted in the seed set in normally segregating families $(46.0$ per cent.) and the abnormally segregating families $(43.5$ per cent.). The figures for germination, however $\left(85^{\cdot 2}\right.$ and 73.3 per cent. respectively), do suggest an elimination of about the proportion required. The discrepancy in the segregating families and the zygotic and pre-zygotic elimination both amount to about is per cent.

\section{(c) Segregation within the resistant lines}

The breeding behaviour of resistant plants is shown in table 4 . All progeny of the single successful cross between resistant plants

TABLE 4

The aberrant segregation of susceptible plants within the resistant lines

Cross type res $\times$ res

\begin{tabular}{|c|c|c|c|c|c|}
\hline \multirow{2}{*}{ Family no. } & \multicolumn{2}{|c|}{$\begin{array}{c}\text { Number of sus and res } \\
\text { ancestors }\end{array}$} & \multirow{2}{*}{$\begin{array}{l}\text { Number of } \\
\text { different } \\
\text { outcrosses } \\
\text { in ancestry }\end{array}$} & \multicolumn{2}{|c|}{ Segregation } \\
\hline & sus & res & & sus & res \\
\hline $86-89$ (4) & $0-3$ & 4- 6 & 2 & o & 68 \\
\hline $90-99$ (IO) & $5-20$ & $7-20$ & $3-8$ & 0 & 207 \\
\hline I OO-I O4 (5) & $5^{-10}$ & $5^{-10}$ & $3-5$ & Io & $20 \mathrm{I}$ \\
\hline $105-108$ & 8- 9 & $7-10$ & $3-5$ & $4^{\circ}$ & 46 \\
\hline
\end{tabular}

derived directly from the original resistant plant were resistant (family 86). This cross was highly infertile and the seed poorly viable and the plants dwarf and abnormal. From approximately 400 florets pollinated, only ig seedlings were obtained ; other crosses of this type were completely infertile.

Other crosses between resistant plants yielded larger families; most of these bred true for resistance but some gave rise to susceptible plants. These aberrant susceptibles on which the first nodules developed normally at the 2-3 leaf stage, were not due to pollen contamination since control selfings remained normally sterile.

The unexpected occurrence of these susceptible plants in what should be pure breeding $r r$ lines may have been due, failing back mutation, to the dilution of the cytoplasmic factor, or to modifying factors or to both. The dilution of a cytoplasmic factor is difficult to envisage in these families since it is presumably under genic control and would be continually produced in the resistant parent plants. Further, the occurrence of susceptible plants bears no relation to the proportion of susceptibles in their recent ancestry, and it does not increase regularly on inbreeding as would be expected on a dilution hypothesis or if due solely to modifying factors. An alternative explanation is, however, suggested by the distribution of these susceptible plants within the resistant lines. Table 4 shows that anomalous 
susceptible plants occur only when the original susceptible parents were likely to be different plants. It has been assumed that the original casual outcross was to a number of plants, as was most probably the case, so that the minimum number of outcrosses is two. In the pedigrees of the anomalously segregating families the number of outcrosses always exceeds two. This relationship obtains whether or not resistant plants are found in the progeny of the outcrosses themselves.

This suggests that some of the outcross material is heterozygous for different resistance factors; the varying ratios indicating that some of these are simple and others more complex. In the families 99, Ioo and 105 one parent was itself a resistant daughter plant of an outcrossed resistant plant (family 138 , table 6), and may therefore be expected to have been heterozygous for one complementary factor only; an approximately equal number of resistant and susceptible plants occur. The parents of family 94 may also have been heterozygous for one additional factor only, and are in fact also related to family 138 .

On this view "aberrant" susceptible plants would therefore be double heterozygotes and on crossing with normal $r_{1} r_{1} R_{2} R_{2}$ plants will give a I : I ratio and when crossed amongst themselves a $9: 7$ ratio. In table 5 data from crosses in which these aberrant susceptible

TABLE 5

The breeding behaviour of aberrant susceptible plants (ab. sus) segregating from pure res parents

\begin{tabular}{|c|c|c|c|c|c|c|}
\hline \multirow{2}{*}{ Family no. } & \multirow{2}{*}{ Type of cross } & \multicolumn{2}{|c|}{$\begin{array}{c}\text { Observed } \\
\text { segregation }\end{array}$} & \multicolumn{2}{|c|}{$\begin{array}{l}\text { Expected } \\
\text { segregation }\end{array}$} & \multirow{2}{*}{$\chi^{2}$} \\
\hline & & sus & res & sus & res & \\
\hline $\begin{array}{l}\text { 001-004 } \\
\text { o05-008 }\end{array}$ & $\begin{array}{l}\text { Ab. sus } \times \text { res } \\
A b . \text { sus } \times \text { sus }\end{array}$ & $\begin{array}{l}74 \\
18\end{array}$ & $\begin{array}{l}63 \\
14\end{array}$ & $\begin{array}{l}68 \cdot 5 \\
16 \cdot 0\end{array}$ & $\begin{array}{l}68 \cdot 5 \\
16 \cdot 0\end{array}$ & $\begin{array}{l}0.883 \\
0.500\end{array}$ \\
\hline $009-012$ & $A b$. sus $\times a b$. sus & 15 & 7 & 12.4 & $9 \cdot 6$ & I. 249 \\
\hline
\end{tabular}

plants are involved support this interpretation. The data in table 5 also agree fairly well with the assumption that the aberrant susceptible plants are heterozygotes produced by back mutation; $\chi^{2}$ for the last two group of families being 6.00 and 0.54 . This explanation fails, however, to relate the occurrence of these 4 families to the outcross family 138.

With regard to the remaining families in table 4 in which only a few aberrant susceptible plants appear, the proportions of susceptibles to resistants (10:20I) corresponds to a $1: 16$ ratio $\left(\chi^{2}, 2 \cdot 016\right)$. This suggests that in these families the effect of the resistance factor may be overcome by a pair of modifying recessive factors. Additional data is clearly needed to substantiate these hypotheses. 


\section{(d) Investigation of maternal inheritance}

The recessive gene for resistance is fairly common in the heterozygous condition in the wild population but its expression in the homozygous form is rare on account of its dependence on the maternally transmitted component which is also rare. The maternal effect will be denoted in the following discussion as being due to a specific substance probably of cytoplasmic origin which will be designated $\rho$.

In table 6 the regular manifestation of maternal inheritance in the outcrosses of resistant plants is demonstrated. In each generation

TABLE 6

The maternal component in the inheritance of resistance

The segregation of resistant plants in outcrosses of resistant plants to unrelated susceptible plants.

\begin{tabular}{|c|c|c|c|c|}
\hline \multirow{2}{*}{ Family no. } & \multirow{2}{*}{$\begin{array}{l}\text { Cross } \\
+\quad 0\end{array}$} & \multirow{2}{*}{$\begin{array}{l}\text { Number of generations separating } \\
\text { resistant parent from original } \\
\text { resistant plant }\end{array}$} & \multicolumn{2}{|c|}{ Segregation } \\
\hline & & & sus & res \\
\hline Original outcross & res $\times$ sus & $\ldots$ & 132 & 17 \\
\hline I $08-$ I I 2 & res $\times$ sus & I & 120 & 18 \\
\hline & recip. & I & 164 & o \\
\hline I I 3-I 35 & $\begin{array}{c}\text { res } \times \text { sus } \\
\text { recip. }\end{array}$ & $\begin{array}{l}\text { I } \\
\text { I }\end{array}$ & $\begin{array}{l}325 \\
386\end{array}$ & $\begin{array}{l}0 \\
0\end{array}$ \\
\hline I $3^{6-1} 3^{8}$ & $\begin{array}{l}\text { res } \times \text { sus } \\
\text { recip. }\end{array}$ & $\begin{array}{l}1 \\
2 \\
2\end{array}$ & $\begin{array}{c}300 \\
92 \\
65\end{array}$ & $\begin{array}{l}4 \\
0\end{array}$ \\
\hline I 39 - I 44 & $\begin{array}{l}\text { res } \times \text { sus } \\
\text { recip. }\end{array}$ & $\begin{array}{l}2 \\
2\end{array}$ & $\begin{array}{l}15 I \\
133\end{array}$ & $\begin{array}{l}o \\
0\end{array}$ \\
\hline I $45^{-1} 4^{8}$ & $\begin{array}{l}\text { res } \times \text { sus } \\
\text { recip. }\end{array}$ & 3 & $\begin{array}{r}204 \\
77\end{array}$ & $\begin{array}{l}4 \\
0\end{array}$ \\
\hline I 49-I 53 & $\begin{array}{l}\text { res } \times \text { sus } \\
\text { recip. }\end{array}$ & $\begin{array}{l}3 \\
3\end{array}$ & $\begin{array}{r}92 \\
101\end{array}$ & $\begin{array}{l}o \\
\text { o }\end{array}$ \\
\hline
\end{tabular}

the outcrosses were to susceptibles of two kinds $(a)$ those which yield no resistant plants in their progeny irrespective of the direction of the cross, and $(b)$ those which give segregation of resistant plants (the susceptible plant acting as paternal parent only).

This division may not always reflect differences in genotype since the ratio of susceptible to resistant plants in the segregating families does not conform to the expected value of $I: I$. This ratio increases from $132:$ I 7 in the original outcrosses (including families which may or may not have given a segregation) to a maximum in the last set of outcrosses of 204:4. Within each group of outcrosses to known susceptibles the proportion of the two types are respectively i $6:$ I I, I $2: \mathrm{I}, 47: 3,30: \mathrm{I}$; and $\mathrm{I} 9: 2,3 \mathrm{I}: \mathrm{I}, 4^{2}: \mathrm{I} ;$ and $33: \mathrm{I}, 5 \mathrm{I}: \mathrm{I}$, $58:$ I, $62:$ I, and thus form series asymptotic to the expected $I: I$ ratio at the original outcross. This result suggests that in the original outcross generation a ratio of $\mathrm{I}:$ I may have obtained. The falling off of the ratio may be due to an elimination of the homozygote $r r$ due to an increasingly inadequate transfer of the $\rho$ cytoplasm. 
In the wild population the homozygous recessive should occur with up to one quarter of the frequency of the heterozygotes. The latter are common in the wild population but there is no evidence that homozygous recessive plants exist in nature ; i.e. the gene $r$ and its analogues may be regarded as lethals which are only viable in the homozygous condition in $\rho$ cytoplasm.

Two other interesting features of this maternal inheritance may be noted : (I) the absence of resistant plants in the outcrosses of susceptible plants derived from the resistant material and (2) its transmission to succeeding generations through the male side.

The first of these features may be illustrated by the following data : 39 heterozygous susceptible plants were outcrossed to unrelated susceptibles, including the susceptible parents of families I08-II2, I $36-\mathrm{I} 38$, I 45-I 48 , and no resistant progeny were obtained. In spite of this, normal inheritance was demonstrated in subsequent generations which again suggests that the cytoplasmic factor was not present in sufficient quantity.

A further slight decrease in the amount of cytoplasmic material transferred would be sufficient to account for the total absence of resistant plants in these crosses. Thus in the resistant outcrosses, excluding the original outcross against which no comparable susceptible outcrosses were available for comparison, 26 resistant plants were found in a population of 1996 , so that in a total population of 1210 plants in the susceptible outcrosses only 5.6 would be resistant.

The second feature of the maternal effect noted above, i.e. that it is transmitted to a succeeding generation through the male side, has already been demonstrated in table $I$ in which the normal behaviour of the gene $r$ is shown. In this table paternal and maternal derivations are not distinguished since no differences were observed; about two-thirds of this material was paternally descended from resistant plants. Also, in table 2 one parent of each of the families 87, 88, $89,95,96,97$ was paternally derived from the original resistant plant and no differences were noted between reciprocals. These facts suggest that the cytoplasmic material $\rho$ is either produced de novo by $r r$ or that enough is transmitted to the embryo via the pollen tube to allow normal expression of $r r$ to take place in the next generation. The first alternative is incompatable with the maternal mode of inheritance described, but the second is in accord with the facts (see text-fig. 2). Whether the maternal factor is a self-reproducing cytoplasmic entity or is under nuclear control, its important function evidently takes place in the embryo sac nurturing the homozygous recessive.

\section{(e) The resistant plant, physiological correlations}

Viability and seed size.-Resistant families have smaller seeds than susceptible families; average weights being I $4 \mathrm{mgm}$. and $2 \cdot 4 \mathrm{mgm}$. respectively. This was most noticeable in family 86 a cross between 
resistant daughters of the original resistant plant, in which all seed was brown and withered, and it is here also that fertility was most impaired $(3 \cdot 1$ per cent. of pollinated florets setting seed compared with 40 per cent. in the remaining resistant families). In later generations the mean seed weight per family varied from $0 \cdot 49 \mathrm{mgm}$. to $2 \cdot 4 \mathrm{mgm}$.

In the resistant families which gave anomalous segregation of susceptible plants (families 99, 100, 105) the seed size was always smaller where the more recently outcrossed plant was the male parent. This suggests that the small seed size is not simply a result of development in the embryo sac of a resistant plant of low vitality but is an expression of the gene $r$; a suggestion also borne out by the larger seed size of progeny of outcrossed resistant plants.

The connection between seed size and resistance in segregating families was examined in a cross between heterozygous plants (family I5) in which large variation in seed size obtained. The material was divided visually into five size classes each containing about the same number of seeds. Of 188 plants 54 were resistant (the $\mathrm{I}: 3$ expectation was 47). Resistant plants occurred in decreasing proportion in the larger size classes ; the numbers of susceptible and resistant plants in the five classes in increasing size order were respectively II $:$ I0, $25:$ I0, $26:$ II $, 34:$ I 4 , and $38: 9$. This result confirms the suggestion that the factor $r$ as well as the cytoplasmic component decreases seed size.

There is thus a connection between seed size and resistance, and an experiment was next undertaken to determine whether artificial shortening of the period of embryo growth within the embryo sac had any effect on the inheritance; it might decrease the proportion of the resistant plants if the cytoplasmic factor is a substance which directly affects resistance.

The experiment was performed using a cross between susceptible plants (family 22). Flower heads were cut prematurely at varying numbers of days after pollination. No seed was obtained by premature harvest earlier than 5 days after pollination and the few seeds obtained ( 15 seeds from 6o florets pollinated) with so short a period of development on the mother plant were not viable. It is interesting to note that this minimum period of preharvest growth of 5 days for the later completion of embryo formation is the same as that noted for barley (Harlan and Pope, 1922) and rye (Nutman, 1943). The results are summarised in table 7 ; there is no effect of premature harvest on the proportions of resistant plants.

The cytoplasmic factor is therefore independent of the length of time of embryo development on the mother plant, and the viability of the resistant plant is not affected by premature harvest.

The mature plant.--No striking abnormality of top or root, other than the absence of nodules, was noted in the original resistant plant. Of its 17 resistant progeny, 12 survived transplanting into soil and a complete record of their appearance was kept. They differed notably 
from susceptible plants in dwarf habit, hairy leaves, leaf chlorosis, and in showing floral abnormalities or in failing entirely to flower.

TABLE 7

Constant proportion of resistant plants in family 22 after normal and premature harvest

\begin{tabular}{|l|c|c|c|c|c|c|c|c|}
\hline $\begin{array}{l}\text { Period of pre-harvest growth } \\
\text { in days } \\
\text { Mean seed weight in mgm. }\end{array}$ & 5 & 7 & 10 & 16 & 20 & 24 & 32 & 40 \\
sus : res. & $0 \cdot 15$ & $0 \cdot 12$ & 0.88 & $1 \cdot 50$ & $1 \cdot 03$ & $2 \cdot 14$ & $2 \cdot 45$ & $2 \cdot 57$ \\
\hline
\end{tabular}

Three produced no upright stems and remained small, three produced short upright stems crowned by a circlet of bracts which soon withered. Six of the resistant plants flowered; one bore white flowers and in the remainder anthocyanin was poorly developed.

In one the flower head was strikingly abnormal, the inflorescence consisting of a cylindrical head of very pale pink florets with normal calyx and reduced corolla parts. In the mature flower the standard was incurved and the wings and keel were open exposing the stigma and stamens which protruded from the flower owing to the suppression of the corolla tube. This aberration later appeared among susceptible derivatives and is possibly due to a single independent factor; it is figured in plate $3(a)$.

In later generations floral and other abnormalities were not so frequent; the leaves remained chlorotic but the plants were less dwarf (see plate I $(b)$ ). Flowering occurred in most of the families raised to the flowering stage though the flower colour was generally pale and the amount of flowering scanty.

Site of resistance: grafting experiments.-So far as root growth and branching are concerned resistant plants were normal (see plate $I(a)$ ). They also responded normally to bacterial secretions in showing roothair deformations. Large numbers of hairs of both resistant and susceptible plants were examined and the proportions of straight, bent, and characteristically curled hairs were the same on each. Roots were also frequently examined for infection threads and none were found. Resistance is therefore absolute, the bacteria failing to gain entry into the host's tissues. It should be noted in this connection that deformation but no penetration of root hairs has been observed with "avirulent strains" (Chen, I938) and with nodule bacteria inoculated to plants of different cross-inoculation groups (McCoy, I 932 ).

Attempts were made to graft together resistant and susceptible plants, with two objects in view : (I) to determine whether resistant or susceptible plants owed their characters to specific substances capable of being translocated across a graft union and (2) to transmit the cytoplasmic effect as such in heredity. 
The second object could of course be achieved only by extensive breeding from grafted plants; and had to be abandoned as only two grafts united of the large number tried.

These are figured in plate II, $(a)$ and $(b)$. The graft " $a$ " (an approach graft) consists of a heterozygous susceptible top grafted on to a resistant root, and the graft " $b$ " (an inarched graft) of a resistant top on a susceptible heterozygous sister root. It will be observed that the resistant root remained unaffected by the presence of a susceptible top and vice versa.

Resistance is therefore not due to the production of an inhibitory substance in the top of the plant which is translocated to the root nor is susceptibility (vis- $\dot{a}$-vis resistance) due to a nodule forming substance produced in the top of the plant and translocated to the root.

The plants figured were replanted and adventitious roots were allowed to develop from above the graft unions, nodules formed only on the adventitious roots developing from the susceptible top. This result suggests that mobile nodule inhibiting or promoting substances are not produced in the root though these experiments do not of course throw any light on the production of either antagonistic or nodule promoting substances which remain in situ in the root.

\section{THE INTERRELATIONSHIPS OF GENE $r$ AND OTHER FACTORS}

A certain amount of incidental data is available with respect to the interrelationships of $r$ with the sterility allelomorphs $\mathrm{S}$, a previously described ineffectiveness factor $i$, and factors determining nodule number and earliness of nodulation. The two latter characters are relevant to the nature of resistance and are conveniently considered at this stage.

\section{(a) Sterility allelomorphs}

Linkage of the gene $r$ with the sterility alleles $\mathrm{S}$ would be shown by marked heterogeneity in for example families 9 to 37 (table 1). These comprise four groups of sib crosses of 4 to 8 families each, and 7 independent families. Only 2 families, one independent, give ratios which depart widely from expectation; the remainder are homogenous $\left(\chi_{(26)}^{2}\right.$ for heterogeneity $\left.=17.6 ; \quad \mathrm{P}=0.9\right)$ showing that the genes $r$ and $\mathrm{S}$ are not linked.

\section{(b) Stage of primary nodulation}

The stage of development (represented by the number of leaves, expanded on the main axis, excluding cotyledons) at which nodule formation begins' has been studied in the experimental stocks. Wide variation occurs in this character in the wild population, and in selected early lines and selected late lines, and in the intermediate lines obtained on intercrossing, suggesting that a number of factors are concerned in the early and late habits of nodule formation. 
The primary nodulation habit is illustrated among resistant line descendants in table 8 . The segregation of resistance and the leaf

TABLE 8

Independent inheritance of resistance and early or late nodulating habit

\begin{tabular}{|c|c|c|c|c|c|c|}
\hline \multirow{2}{*}{ Family nos. } & \multicolumn{3}{|c|}{ Resistance } & \multicolumn{3}{|c|}{$\begin{array}{c}\text { Primary nodulating habit } \\
\mathrm{E}=\text { Early nodulation } \\
\mathrm{L}=\text { Late nodulation }\end{array}$} \\
\hline & $\begin{array}{l}\text { Type of } \\
\text { cross }\end{array}$ & Obs. & Exp. & $\begin{array}{c}\text { Type of } \\
\text { cross }\end{array}$ & $\begin{array}{c}\text { Number of } \\
\text { plants }\end{array}$ & $\begin{array}{l}\text { Mean progeny } \\
\text { leaf number at } \\
\text { infection }\end{array}$ \\
\hline $\begin{array}{l}\log * \\
\operatorname{li} 5 \dagger\end{array}$ & $\begin{array}{c}r r \times R \\
\text { (outcross) }\end{array}$ & $\begin{array}{l}4 \\
3\end{array}$ & ? & $\begin{array}{l}? \times \mathrm{E} \\
? \times \mathrm{L}\end{array}$ & $\begin{array}{r}130 \\
9^{2}\end{array}$ & $\begin{array}{l}2 \cdot 3^{2} \\
2 \cdot 7^{2}\end{array}$ \\
\hline $\begin{array}{l}167 \\
168 \\
169\end{array}$ & $\begin{array}{c}R r \times R \\
\text { (outcross) }\end{array}$ & $\begin{array}{l}0 \\
0 \\
0\end{array}$ & $\begin{array}{l}0 \\
0 \\
0\end{array}$ & $\begin{array}{l}\mathrm{E} \times \mathrm{E} \\
\mathrm{E} \times \mathrm{L} \\
\mathrm{L} \times \mathrm{L}\end{array}$ & $\begin{array}{l}32 \\
25 \\
50\end{array}$ & $\begin{array}{l}1 \cdot 92 \\
2 \cdot 14 \\
3 \cdot 14\end{array}$ \\
\hline $\begin{array}{l}3,4 \\
\mathrm{I}, 2\end{array}$ & $r r \times R r$ & $\begin{array}{l}32 \\
43\end{array}$ & $\begin{array}{l}39 \\
35\end{array}$ & $\begin{array}{l}? \times \mathrm{E} \\
? \times \mathrm{L}\end{array}$ & $\begin{array}{l}35 \\
28\end{array}$ & $\begin{array}{l}3.10 \\
4.00\end{array}$ \\
\hline $\begin{array}{l}28 \\
15 \pm \\
19 \$\end{array}$ & $R r \times R r$ & $\begin{array}{r}3 \\
74 \\
34\end{array}$ & $\begin{array}{l}7^{8} \cdot 25 \\
21 \cdot 75\end{array}$ & $\begin{array}{l}\mathrm{E} \times \mathrm{E} \\
\mathrm{E} \times \mathrm{L} \\
\mathrm{L} \times \mathrm{L}\end{array}$ & $\begin{array}{r}17 \\
\text { I } 16 \\
68\end{array}$ & $\begin{array}{l}2 \cdot 91 \\
3 \cdot 13 \\
3 \cdot 4^{0}\end{array}$ \\
\hline
\end{tabular}

* rog, also $110,125,128,140 . \dagger 115$, also $130,137,146,152 .+15$, also $18,27,29,30$. § 19, also $20,21,26$.

number at primary nodulation is indicated. Among the susceptible progeny of the various crosses the parental types are simply classified as, either early (E), or late (L), in nodulating habit, i.e as nodulating with less than $2 \frac{1}{2}$ or more than 3 leaves respectively.

These results show that the progeny of outcrossed resistant plants (families 109, etc., and I I 5, etc.) are partly dependent in nodulating habit on the susceptible parent. Resistant plants appear therefore to vary in factors affecting earliness in nodulation. This is confirmed in the remaining data in the table; within each type of cross the proportion of resistant plants is not significantly greater among plants of late habit than among other types. The genetic factors which determine the time at which primary infection of the root takes place, thus segregate independently of the gene $r$.

\section{(c) Number of nodules}

The number of nodules which develop on the roots of clover are genetically determined. The crossing of contrasting types leads to intermediate types in $F_{1}$, as was noted in the previous quantitative character. Since the number of nodules also depends on conditions of growth (duration, bacterial strain inoculated and the volume of 
the root medium) only an approximate classification can be made of parental types selected at different times, and the results of different experiments cannot be so well collated. Accordingly the inheritance of density of nodule formation and resistance in two separate experiments is shown in table 9 with for comparison (experiment I) the

TABLE 9

Independent inheritance of resistance and of factors affecting the numbers of Nodules formed on the root

\begin{tabular}{|c|c|c|c|c|c|c|}
\hline \multirow{3}{*}{ Family no. } & \multicolumn{3}{|c|}{ Resistance } & \multicolumn{2}{|c|}{ No. of nodules } & \multirow{3}{*}{$\begin{array}{l}\text { Rank correlation } \\
\text { Spearman's } \rho\end{array}$} \\
\hline & \multirow{2}{*}{ Type of cross } & \multicolumn{2}{|c|}{$\begin{array}{l}\text { No. of resistant } \\
\text { plants }\end{array}$} & \multirow{2}{*}{$\begin{array}{c}\text { Parental } \\
\text { nodule } \\
\text { no. }\end{array}$} & \multirow{2}{*}{$\begin{array}{c}\text { Progeny } \\
\text { nodule no. } \\
\text { (mean) }\end{array}$} & \\
\hline & & Obs. & Exp. & & & \\
\hline \multirow[t]{3}{*}{ Experiment I } & & & & & & \multirow{10}{*}{$(\mathbf{P} \stackrel{0.943}{=} 0.999)$} \\
\hline & $R \times R$ (unrelated) & $\ldots$ & $\cdots$ & $\begin{array}{r}6 \times 20 \\
62 \times 6\end{array}$ & $\begin{array}{l}18 \cdot 7 \\
21 \cdot 2\end{array}$ & \\
\hline & $"$ & $\ldots$ & $\ldots$ & $89 \times 6$ & $24 \cdot 6$ & \\
\hline \multirow{3}{*}{$\begin{array}{c}\text { Experiment } 2 \\
\text { I } 16\end{array}$} & $"$ & $\cdots$ & $\cdots$ & $89 \times 62$ & $40 \cdot 7$ & \\
\hline & $r r \times R$ & o & ? & $o \times 6$ & $16 \cdot 2$ & \\
\hline & $r r \times R$ (outcross) & 0 & ? & $0 \times 10$ & $20 \cdot I$ & \\
\hline IIO & , & I & ? & $0 \times 15$ & $18 \cdot 9$ & \\
\hline II 4 & ", & 0 & $?$ & $0 \times 16$ & $27 \cdot 2$ & \\
\hline 117 & ", & o & $?$ & $0 \times 20$ & $29 \cdot 7$ & \\
\hline \multirow{2}{*}{$\begin{array}{l}112 \\
\text { Experiment } 3\end{array}$} & ," & I & $?$ & $0 \times 62$ & 347 & \\
\hline & $R r \times R r$ & 35 & $31 \cdot 0$ & $17 \times 17$ & $19 \cdot 7$ & \multirow{7}{*}{$(\mathrm{P} \stackrel{0.714}{=0.967})$} \\
\hline 37 & ,, & 3 & $14 \cdot 25$ & $23 \times 17$ & $15 \cdot 6$ & \\
\hline 33 & ," & 24 & $18 \cdot 25$ & $20 \times 21$ & $19 \cdot 4$ & \\
\hline 35 & ," & I3 & $16 \cdot 25$ & $23 \times 23$ & $17 \cdot 3$ & \\
\hline $3^{6}$ & ", & 28 & $27 \cdot 5$ & $35 \times 5^{1}$ & $3^{2 \cdot 0}$ & \\
\hline 34 & ," & Io & $7 \cdot 75$ & $3^{8} \times 5^{1}$ & 43.4 & \\
\hline $3^{2}$ & ", & 12 & $14 \cdot 25$ & $20 \times 74$ & $32 \cdot 8$ & \\
\hline
\end{tabular}

number of nodules formed in crosses between some of the susceptible plants used in the original outcrosses of resistant plants.

Within each experiment the families have been arranged in order according to the sum of the parental nodule numbers, and Spearman's rank correlation test (Kendal, 1947) has been applied to the mean progeny nodule numbers. In each experiment the correlation between parental and progeny number is highly significant.

Although the progeny of resistant outcrosses (experiment 2) broadly reflect their susceptible parents in this character, the range of difference is less than in experiment $\mathrm{r}$, suggesting that the genotypes of the resistant plants correspond to an intermediate number of nodules. These results show that resistance does not correspond genetically to an extreme form of sparse nodulation. 


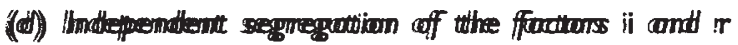

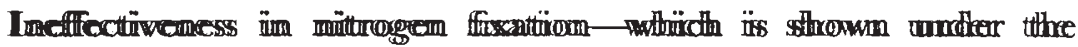

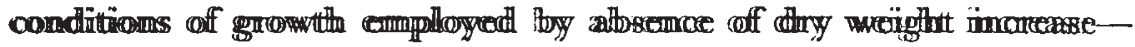

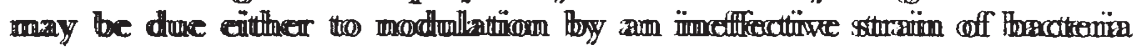

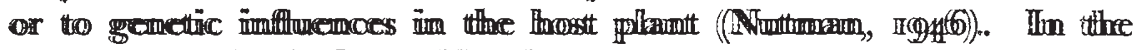

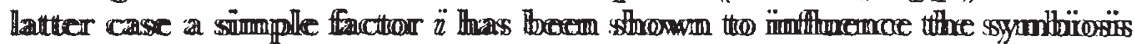

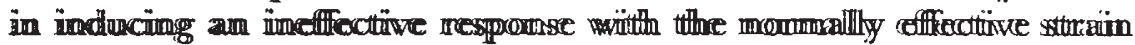

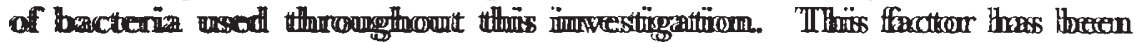

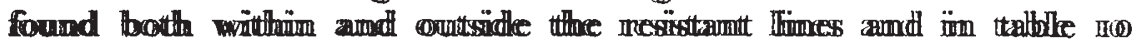

TIARILE INo

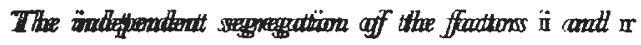

((II, effecotisise. iii, imeffiectivive.))

\begin{tabular}{|c|c|c|c|c|c|c|}
\hline \multirow{3}{*}{ Faumently Inta. } & \multicolumn{2}{|c|}{ Chrows type } & \multicolumn{3}{|c|}{ Effectbivenew } & \multirow{3}{*}{$x^{2}$} \\
\hline & \multirow{2}{*}{ RRerïtramere } & \multirow{2}{*}{ 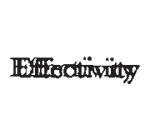 } & \multicolumn{2}{|c|}{ (Otbrented } & \multirow{2}{*}{$\begin{array}{l}\text { Drevination ifrom } \\
\text { cexppecotatioion }\end{array}$} & \\
\hline & & & II & iiji & & \\
\hline $\begin{array}{c}4,5 \\
60,7 \\
17=2010 \\
18\end{array}$ & 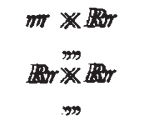 & 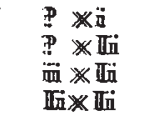 & $\begin{array}{l}115 \\
177 \\
1122 \\
106\end{array}$ & $\begin{array}{r}177 \\
5 \\
76 \\
76\end{array}$ & $\begin{array}{l}+100 \\
+105 \\
+20 \\
+1.255\end{array}$ & 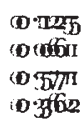 \\
\hline
\end{tabular}

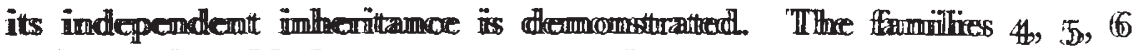

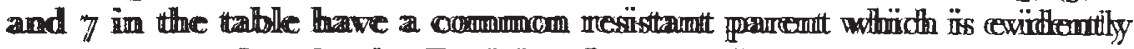

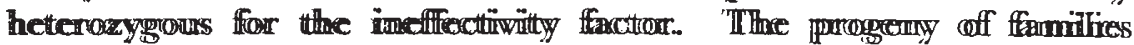

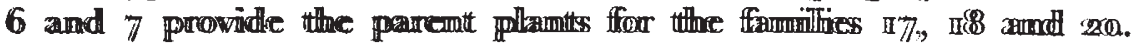

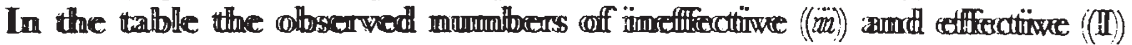

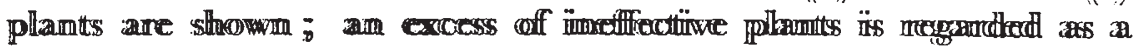
positive devizatticom.

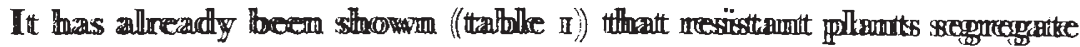

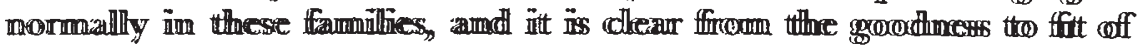
the segregations fror the geme $\ddot{u}$ theatt ïts

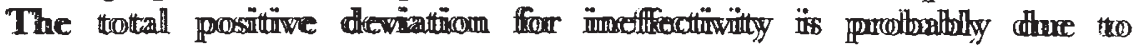
inbreedirng.

\section{GENETIIC ABNOORMALIITIIES INI THHE RESISTTANIT UINESS ANDD DEERNVATINVESS}

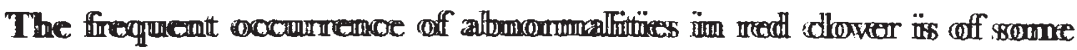

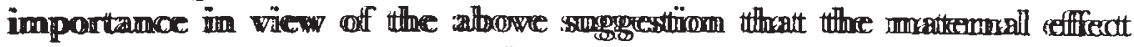

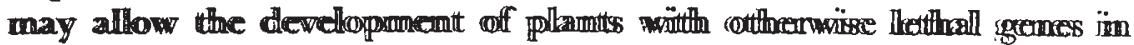

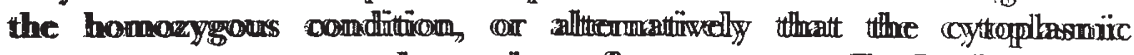

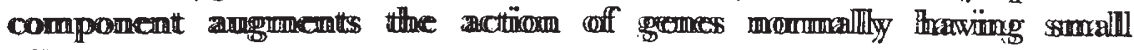
effects. 
Complete records have been kept of the very great variety of observed aberrations and for convenience they have been classified into two main categories: (I) those which appear, often on slender evidence, to be inherited as simple recessives, and (2) those which have no clear mode of inheritance. The second category comprise abnormal germination, dwarfing, chlorosis, variegation, cotyledon deformation, etc.

\section{(a) Simple recessives}

The distributions of six recessive factors in the resistant line material and its derivatives (about 200 families), and in about the same number of unrelated families are listed in table II. The following are brief descriptions of these forms :-

Albino w.-Williams (1939) distinguished 8 albino recessive factors. Some pure white, others cream or golden seedlings; similar distinctions found in present material.

TABLE II

The distribution of simply inherited abnormalities within and outside the resistant lines and derivatives

\begin{tabular}{|c|c|c|c|c|c|}
\hline \multirow{2}{*}{ Character } & \multirow{2}{*}{ Family no. } & \multicolumn{3}{|c|}{ Segregation } & \multirow{2}{*}{$\begin{array}{l}\text { No. of non- } \\
\text { segregating } \\
\text { related } \\
\text { families }\end{array}$} \\
\hline & & Normal & Mutant & $\chi^{2}$ & \\
\hline $\begin{array}{l}\text { Blue-green } \\
\text { Dwarf bgd } \\
\text { Crimped leaf } c l \\
\text { Pink flush pf } \\
\text { Stump root sr } \\
\text { Raspberry head } \text { rh }\end{array}$ & $\begin{array}{c}23,79-82, \text { I } 77, \text { I } 93(7) \\
50,62,63,74,84(5) \\
34(1) \\
\ldots(4) \\
\ldots .(2) \\
26(1) \\
\ldots(1) \\
\ldots(3) \\
\text { 180, r } 81(2) \\
\ldots \text { (1) } \\
\text { progeny of original outcrosses } \\
\text { ro2, ro4 (2) }\end{array}$ & $\begin{array}{r}173 \\
121 \\
33 \\
67 \\
31 \\
29 \\
13 \\
28 \\
31 \\
21 \\
\ldots \\
9\end{array}$ & $\begin{array}{r}48 \\
27 \\
8 \\
20 \\
13 \\
9 \\
3 \\
9 \\
13 \\
8 \\
1 \\
4\end{array}$ & $\begin{array}{l}20 \cdot 84 \\
12 \cdot 08 \\
0.66 \\
2 \cdot 68 \\
2 \cdot 49 \\
0 \cdot 04 \\
0.33 \\
0.33 \\
I \cdot 85 \\
0.10 \\
\ldots . \\
0.24\end{array}$ & $\begin{array}{r}5 \\
10 \\
2 \\
4 \\
1 \\
4 \\
1 \\
2 \\
0 \\
0 \\
\dddot{0} \\
\ddot{(?)}\end{array}$ \\
\hline
\end{tabular}

Five cases of single factor albinism encountered; three among descendants of the resistant plant, two elsewhere.

Overall ratios support a single factor basis, but great variation between families occurred in the first two instances: linkage with the $\mathrm{S}$ factor may be involved as demonstrated for factor $w_{1}$ by Williams ( I939).

Blue-green dwarf, bgd.-Cotyledon size and colour normal, the first leaf blade much reduced, generally irregularly triangular in shape, dark in colour. Succeeding leaflets remain infolded, hairier than normal leaves. No effective growth is made, a plant becoming smaller as each withered leaf is replaced by a smaller succeeding one. Semilethal, no flowers are produced although a single plant transferred to soil survived for 9 months. Resistant and susceptible blue-green dwarfs occur in family 26 . Both types of seedlings with an older 
plant are illustrated in plate III, $(b)$ and $(c)$. The character is due to reduction in the cell size without reduction in plastic number or size. Affected cells have denser protoplasmic contents, only vacuolated along mid-rib of leaf.

Outside the resistant material blue-green dwarfs appeared among $F_{2}$ plants of a cross between unrelated susceptible plants one of which was, however, related to family 26 . The original resistant plant was therefore probably not heterozygous for this character.

Crimped leaf, cl.-Morphologically related to blue-green dwarf as it concerns abnormal leaflet infolding and is progressive. The first four leaves normal but leaflets of following leaves do not unfold. Infolding at first restricted to the tip of the leaflet, extends in later leaves to include the whole length of mid-rib, and occasionally the whole of the breadth of the leaflet. Probably inherited as a simple recessive, does not occur among resistant plants and their descendants.

Raspberry head, th.-Described above in the description of resistant plants. The inflorescence has compact appearance resembling a large unripe raspberry (see plate III $(a)$ ). First appeared in the progeny of the original outcrossed resistant plant which was therefore heterozygous for this character, confirmed by its later appearance among descendants of other outcrosses.

The data available is very sparse; a simple factor probably concerned. Original raspberry headed plant resistant; of the four later ones two resistant and two susceptible.

Pink flush, $p f$.- A bright pink colouration of hypocotyl and upper part of primary root, usually extending into and intensified in first nodules; intensity of colouration varies. Appeared in two families with one common parent. Improbable that the original resistant plant was heterozygous for this factor.

This recessive is of some interest in view of the recent work on hæmoglobin in nodules (Keilin and Wang, 194j; Virtanen, 1945). Section of pink-flush nodules show that the colour is developed in the nodule rind whereas hæmoglobin is confined to the bacterial tissue.

Stump root, sr.-Very slow growth in length of roots, few branches, a dark brown-green colouration of surface of root. Nodules form sparsely, tend to grow to large size as shown in plate III, $(d)$. Tops are at first normal, become dwarfed and withered, probably due to interruption in uptake of nutrients. Occurs only in one family, unrelated to the resistant lines.

The distribution of these six recessives in the experimental stocks shows that simply inherited abnormalities do not appear to be more or less frequent than usual among the descendants of the original resistant plant.

\section{(b) Genetically indeterminate forms}

The various types of abnormality of indeterminate inheritance in material of different origin are not separately listed in tables 12 and 13 , 


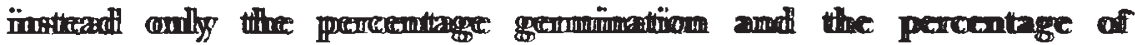

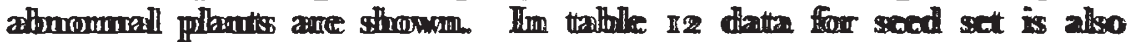
inctherthedth.

TAABLE'

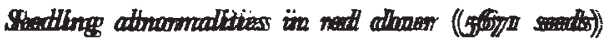

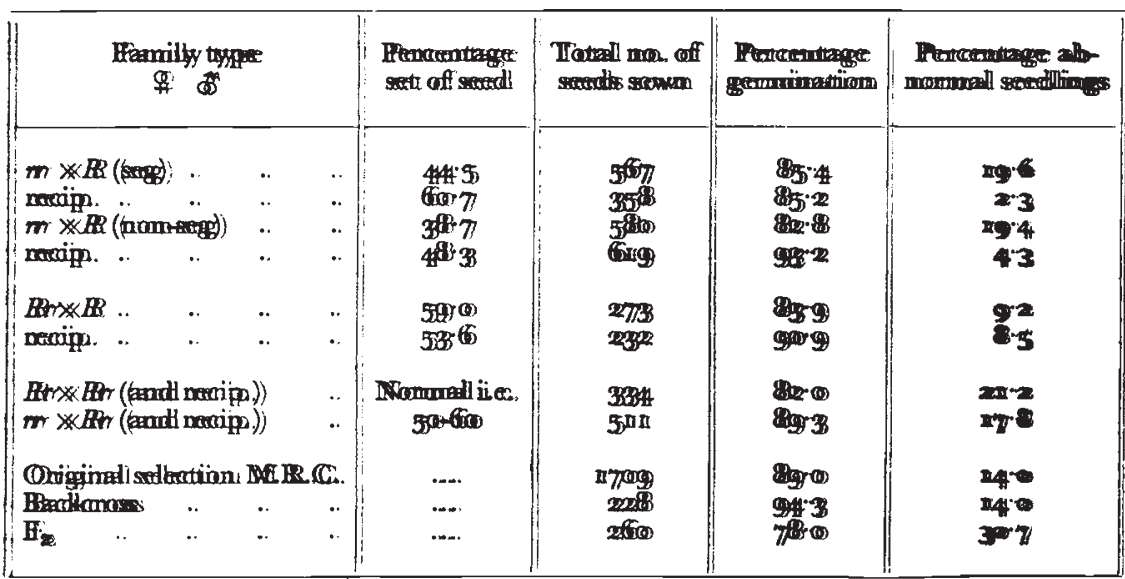

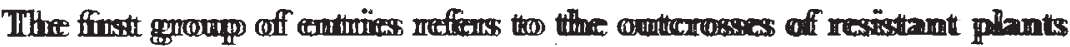

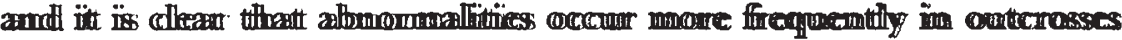

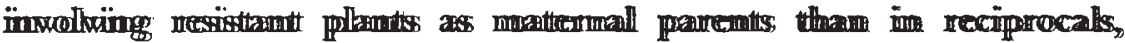

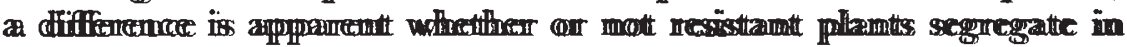
the formilives concremedt.

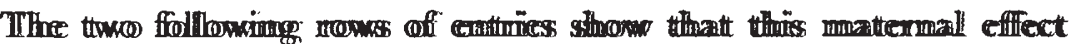

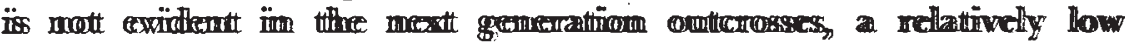

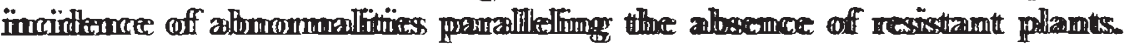
The mextt typpess off crosss sthrown indticatie thant the propportion of

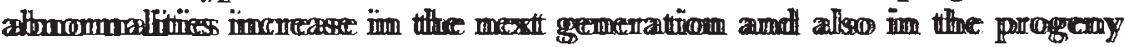

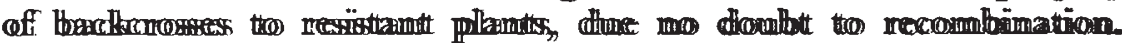

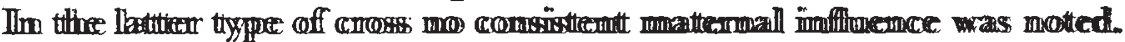

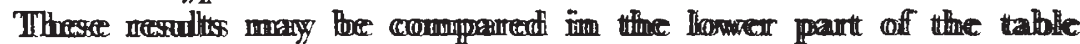

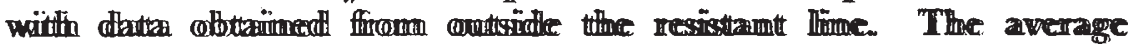

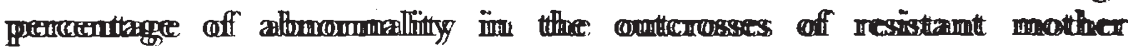

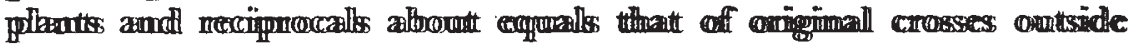

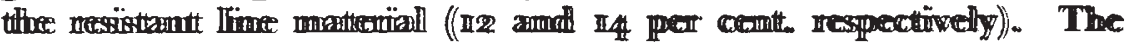

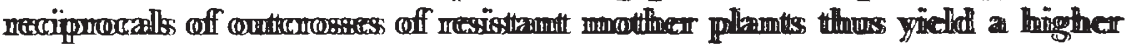

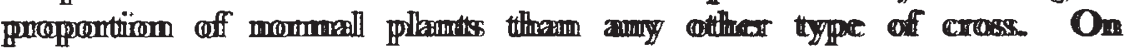

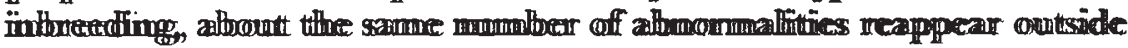

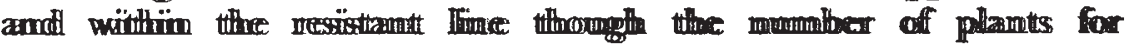
compranisom there is mott largere

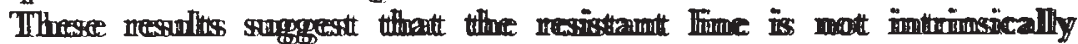

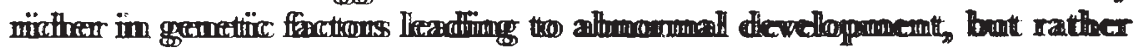

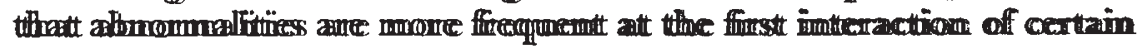

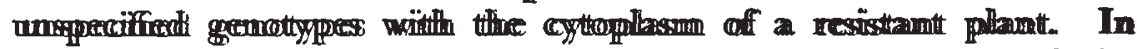

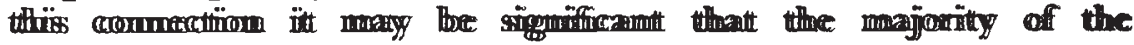


abnormalities listed are seedling characters; later development being mostly normal. This holds for most forms of dwarfing and for variegation which is largely confined to the cotyledons and is rarely systemic. Leaf abnormalities are generally confined to the first and secand leaves, the most frequent being the occurrence of two opposite and decussate unifoliate "first" leaves instead of a single unifoliate first leaf. The principal root abnormality is the abortion of the primary radicle.

Throughout this phenomenon there appears therefore to be a disorganising maternal influence which becomes less potent as the plant develops; only in the case of the resistant character, which is a mature plant character, is the maternal influence persistent and perpetuated. This confirms the suggestion already made that the maternal influence is itself a product of the resistant factor $r$.

Outside the resistant line considerable and quite significant differences between reciprocals are not infrequent. The distinction, however, between the occurrence of maternal effects in the two kinds of material is that in the resistant outcrosses the differences between reciprocals are consistently in one direction. It is possible that if an hereditary character were available to sort out the maternal effects outside the resistant line a similar disposition of the abnormalities would be found. shown.

In table 13 the seedling abnormalities of resistant families are TABLE 13

Distribution of seedling abnormalities in the resistant line

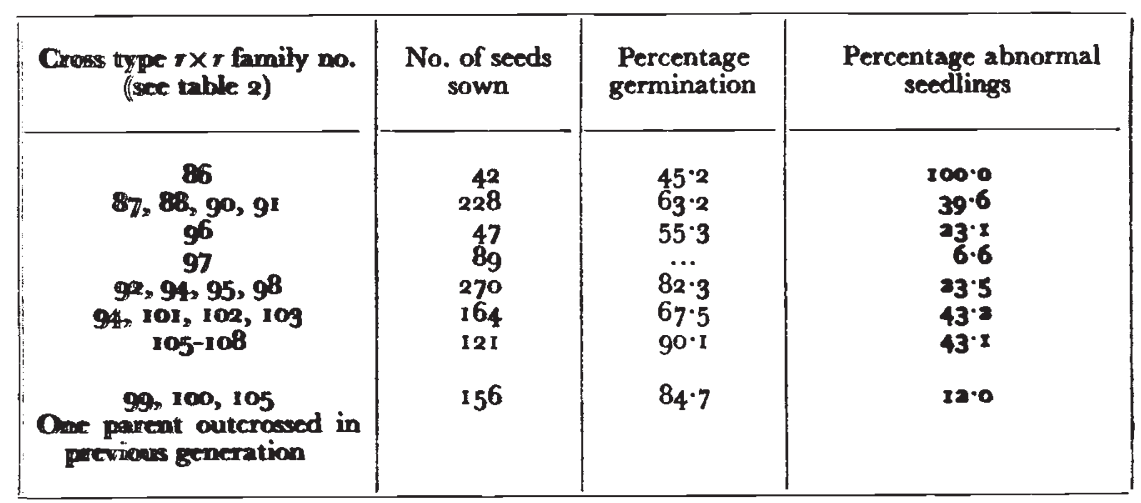

With the exception of the last group (families 99, 100, 105), the families are arranged according to the closeness of their relation to the original resistant plant; the seventh group (families 105-108) being four to five generations removed from the original resistant plant.

Progeny of the crosses between resistant daughter plants of the original resistant plant (family 86 ) show a maximum number of abnormalities, which was reflected in both the high incidence of 
dwarfing, abnormal germination, chlorosis, etc., and also in a high proportion of non-viable seed.

In later generations some of the abnormalities have been eliminated and the proportion of normal plants tends to increase and appears to be of the same magnitude as in comparatively inbred material outside the resistant line. Although the material is descended from a single parental resistant plant, a number of different susceptible plants entered into the ancestry in outcrosses. For example the family 97 in the table is derived from four different susceptible plants and as a result the effects of inbreeding are not so evident. In the last three families listed in the table recent outcrossing to unrelated susceptible plants has taken place and the normal type of growth has been restored.

The large numbers of abnormalities which appear in resistant crosses and in resistant outcrosşes do not appear to be open to interpretation along orthodox genetic lines.

The alternative physiological explanation, i.e. that they simply reflect the impaired nutrition of the embryo is genetically insufficient because it fails to account for the correlation between the distribution of these abnormalities in this material and the maternal component in the inheritance of resistance itself. This aspect has accordingly been dealt with in some detail and its relation to other cases of extra-chromosomal inheritance will be more fully discussed below.

\section{GENETICAL ASPECTS OF RESISTANCE}

The principal genetic interest in resistance lies in the cytoplasmic gene interactions which have been disclosed, and in fig. I simplified pedigrees illustrate the essential features of the inheritance.

The original hypothesis was that the inheritance of resistance might be explained by the simple interaction of a recessive gene with a cytoplasmic component. This has proved not to account for all the facts. The results at variance with this simple hypothesis are of two kinds : (i) the partial or complete elimination of resistant plants in mixed families of various origin-marked as a crossed circle in fig. I ; and (ii) the intrusion of susceptibles in the resistant lines.

(i) The degree of elimination of resistant homozygotes in different crosses is shown in table 14 . In the original outcross probably no elimination occurred but in each succeeding generation of outcross of resistant mother plants with unrelated susceptibles of type $B$ the elimination becomes more marked; it is everywhere complete in the reciprocal crosses and in crosses among susceptibles of type B.

In these outcrosses this elimination is correlated with the maternal mode of inheritance and has been ascribed to the absence of $\rho$ cytoplasm in the embryo-sac of the susceptible parent. The depression of seed set in the families in which elimination occurs only partly accounts for the deficiency of resistant plants and germination is 
(i)

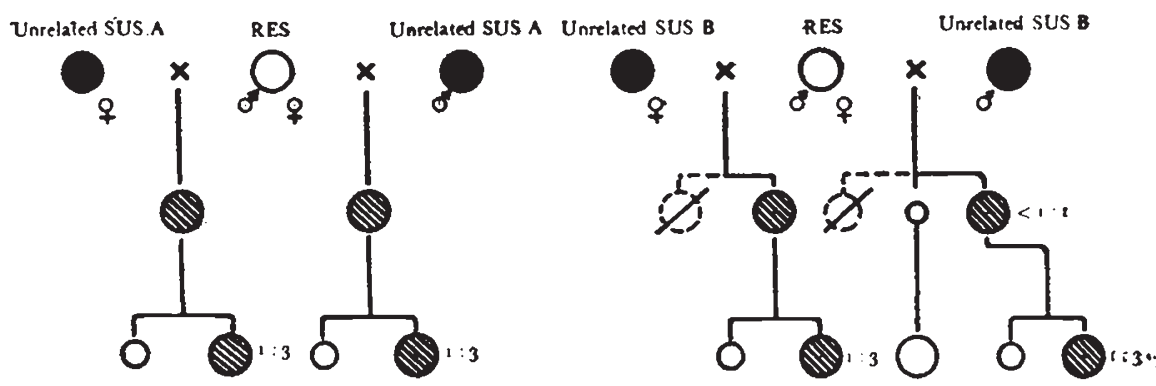

(iii)
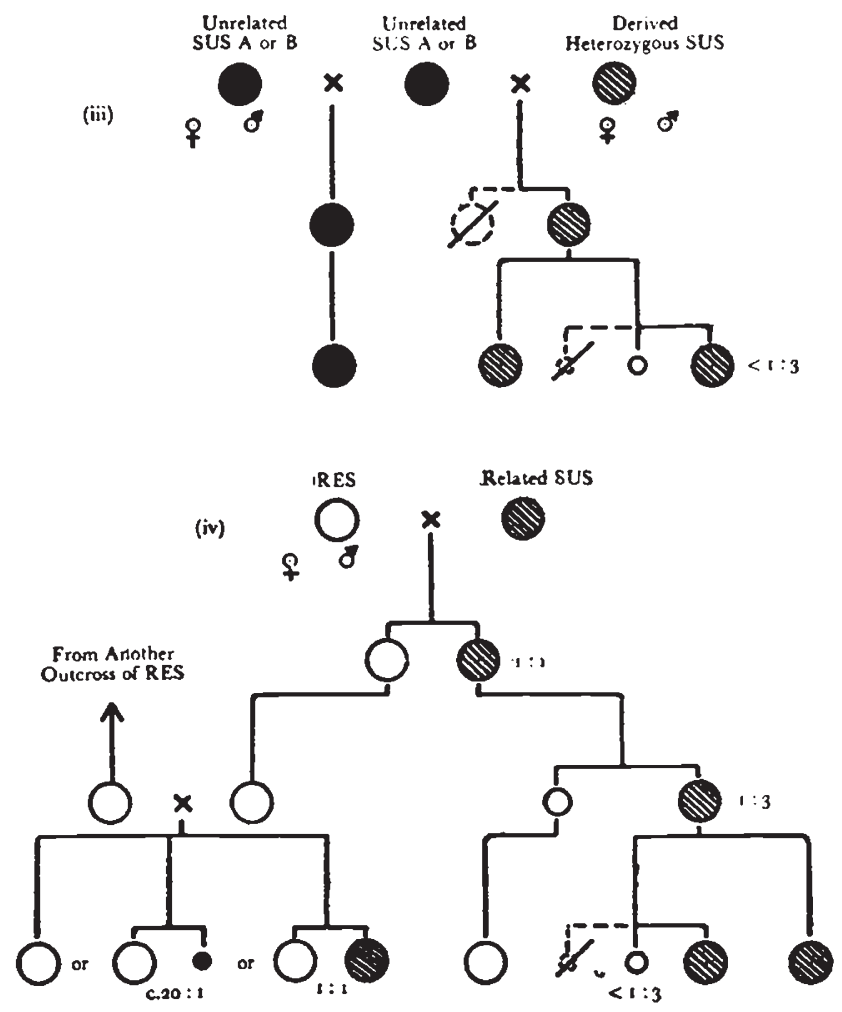

FIG. I.-Abridged pedigrees illustrating the inheritance of resistance (lines of descent from single type plants represent sib matings). Unrelated susceptible plants shown by black circles and susceptibles related to resistants by hatched circles; resistant plants shown by open circles; relative proportion indicated by size of circle. Elimination of resistant plants indicated by crossed out circles. (i) and (ii) show reciprocal crosses of res $F_{1}$ plants with unrelated susceptibles of types $A$ and $B$. With type $A$, no resistants appear in progeny; with type B, resistant plants appear as less than half the daughter plants of resistant mothers. In remaining crosses a normal i : 3 ratio occurs of the resistant plants breed true. (iii) shows the pure breeding of unrelated susceptibles and the elimination of resistants in crosses of derived susceptibles with unrelated susceptibles. (iv) shows segregation following the crossing of related resistant and susceptible plants. The deficiency of resistant plants in mixed families with an intercalary susceptible generation, and the appearance of anomalous susceptibles in some resistant lines is also indicated. 
normal. The elimination must therefore take place at a pre-fertilisation stage. This also applies to all the crosses where elimination is complete. These relationships are all consonant with the view that the gene r is lethal except in the presence of $\rho$ cytoplasm.

\section{TABLE 14}

The elimination of resistant plants in genotypically mixed fannilies of differing origin

\begin{tabular}{|c|c|c|}
\hline Family & $\begin{array}{c}\text { Elimination of recessive } \\
\text { homozygotes }\end{array}$ & Remarls \\
\hline 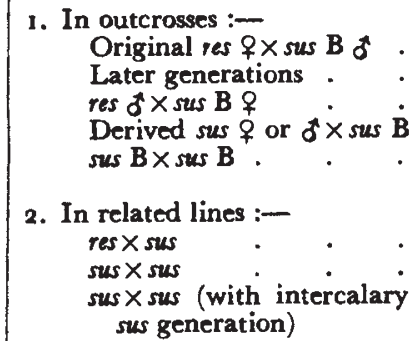 & $\begin{array}{l}\text { Probably none } \\
\text { Progressive elimination } \\
\text { Complete } \\
\text { ", } \\
\text { "" }\end{array}$ & 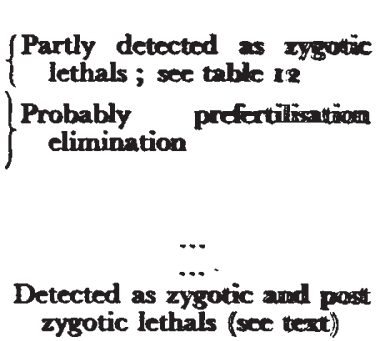 \\
\hline
\end{tabular}

The progressive nature of the elimination in succeeding generations of outcrosses remains unexplained. It suggests an adaptation between the gene $r$ and $\rho$ cytoplasm leading eventually to the disappearance of the maternal effect and an apparent simplification of the inheritance.

In crosses involving related susceptible and resistant plants, elimination only occurs where a susceptible generation is interposed between the parents of the cross in question and a resistant ancestor ; here the elimination is partial and can be accounted for as due to zygotic and post-zygotic lethals. This deficiency of resistants may also be due to the lethal character of the gene $r$ in the absence of the cytoplasmic substance. One further assumption is required, wiz. that the relation between the gene $r$ and $\rho$ cytoplasm is complementary; just as the gene $r$ is lethal in absence of $\rho$ cytoplasm, so the $\rho$ cytoplasm cannot be indefinitely produced or is produced at a decreased rate in the absence of $r$. With this assumption it is clear that with an intercalary susceptible generation a dilution of the $\rho$ cytoplasm could occur and this would lead to the elimination of resistants. Here elimination occurs at a later stage than in outcrosses, i.e. by zygotic and post-zygotic lethals.

(ii) In contrast to the above, an explanation of the occurrence of susceptible plaits in crosses between resistant parents has already been offered in terms of additional genetic factors and is supported by breeding experiments. Here resistant factors are always present and the cytoplasmic component may be supposed to be under constant production. 


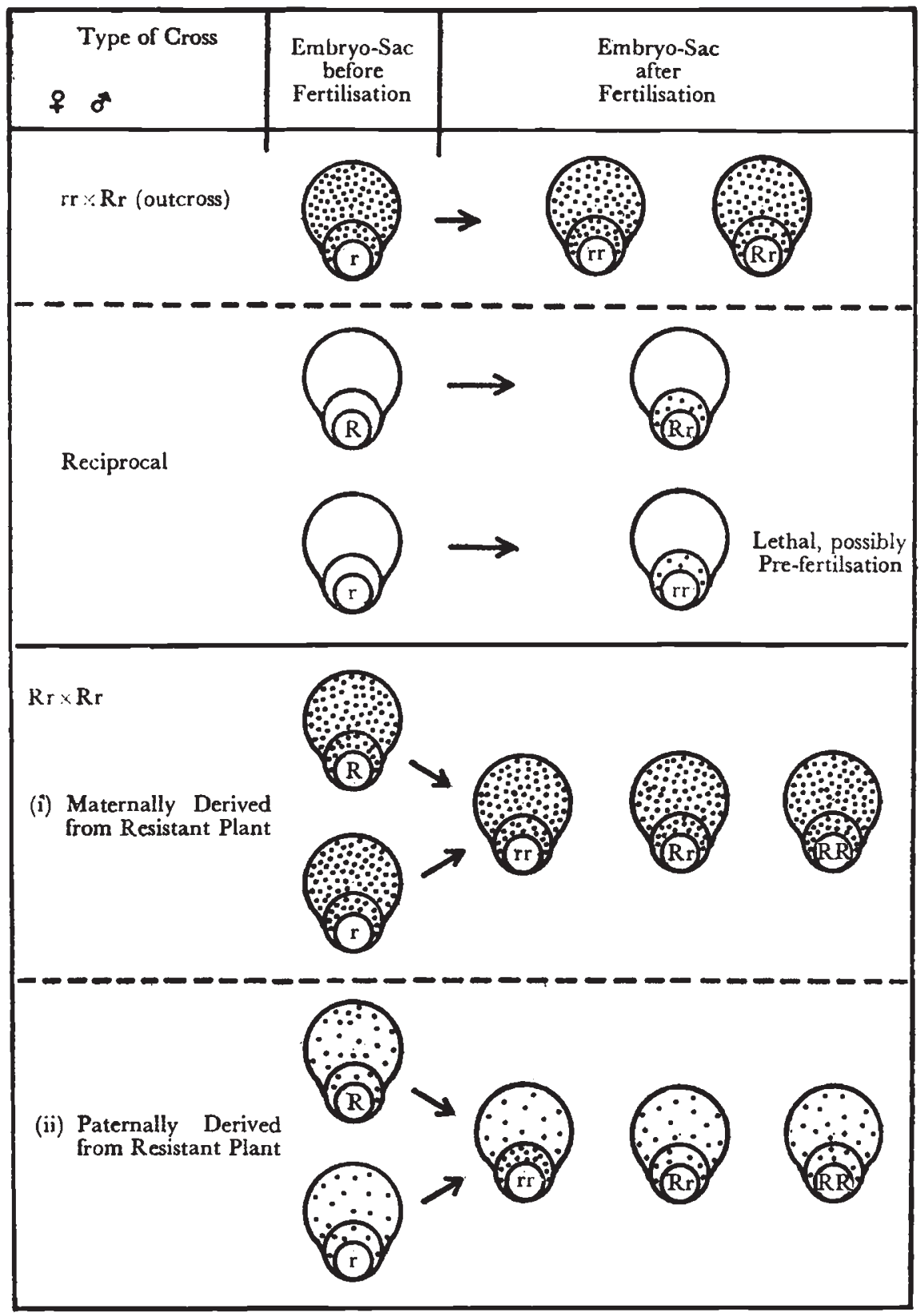

Frg. 2.-An explanation of the maternal inheritance in terms of the location of the cytoplasmic resistance material $\rho$, which is represented in the diagrams by heavy stippling when transmitted through the egg and light stippling when transmitted through the pollen. 
It is therefore suggested that the original hypothesis be modified as follows : ( $I$ ) the resistant condition is due to the interaction of one of a number of simple recessive genes with cytoplasm of the specific constitution $\rho ;(2)$ the $\rho$ cytoplasm is not self-reproducing or has limited powers of self-reproduction but is itself a product of the gene $r$; (3) the homozygote $r$ is lethal in the absence of $\rho$ cytoplasm.

The effective production of the specific cytoplasm leading to resistance therefore requires both the homozygous recessive genetic factor and the presence of a quantity of this substance in the developing embryo-sac which is to contain the recessive zygote. This substance may either enter the egg cell from the embryo-sac of a resistant female or else be carried over in the pollen of the preceding generation.

Using the symbols $\rho$ to represent resistant cytoplasm and $\mathrm{R}$ and $r$ to designate the genes concerned, the condition of embryo development in segregating resistant outcrosses and in the following generation are schematically represented in fig. 2 .

The scheme calls to mind gene-cytoplasm interactions described in a number of cases of maternal non-Mendelian inheritance in plants; particularly in male sterility in flax (Bateson and Gairdner, I92I ; Chittenden and Pellew, I927) and chlorophyll striping in maize (Rhoades, I 943).

The intussusception of a genetically determined cytoplasmic entity (plasma gene) which may be self perpetuating, or at any rate can be transmitted from parent to offspring, is also postulated among microorganisms in the inheritance of certain adaptive enzymes in yeast (Winge and Lausten, I940 ; Lindegren, I945) and for the "killer" character in Paramecium (Sonneborn, I946). The $\rho$ cytoplasm of resistant plants resembles the kappa $(K)$ substance in Paramecium in that some of the substance must be present before genetic factors can have any influence on its further production, but it differs from this substance in that the associated recessive factor is lethal in its absence.

Non-Mendelian inheritance of a different order has also been demonstrated in plants by the work of Michaelis (1937) on Epilobium species hybrids, by Sirks (I93I) on Vicia species hybrids and by Wettstein (1928) in mosses.

The present researches may form a link between these two types. On the one hand the resistance-type cytoplasm has specific effects, and on the other hand it contributes to the appearance of abnormal seedling characters such as dwarfing, chlorosis, variegation, etc., in the outcrosses of resistant $q$ plants ; possibly due to gene-cytoplasm interactions.

Further, from the extensive survey outside the resistant line and its derivatives, it has been shown that examples of non-Mendelian inheritance involving similar kinds of seedling abnormality are fairly widespread in the wild population of red clover. That these sporadic cases may be explained in similar terms is suggested by their occurrence 
with the same relative frequency as within the outcrosses of resistant plants irrespective of the direction of the cross. The fact that abnormalities occur much more frequently in the outcrosses of resistant o plants than in the reciprocal crosses, which show the highest proportion of normal plants, again suggests a correspondence between these maternal effects inside and outside the resistant line material. That these reciprocal differences are not generally remarked, and their maternal mode of inheritance studied, is possibly because the genetic factors responsible for the multiplication of the cytoplasmic component have not been detected. Within the resistant line outcrosses the maternal effects can be distinguished because they are controlled by a mutant gene affecting a simple character (as in Paramecium). The almost complete elimination of abnormalities in the crosses of sus $+\times r e s$ of also suggests, either that there are few mutant loci able to affect the cytoplasm in this way, or that different mutations may have similar effects on the gene-cytoplasm interaction.

\section{RESISTANCE IN LEGUME SYMBIOSIS}

In symbiosis resistance is a relative term, and iis use is not always appropriate. Gaumann (1946) has shown that a similar problem of definition is met with in pathology, particularly in for example rust fungi infections, and he suggests that total absence of infection is not properly described as resistance since no detectable response of the host plant is invoked. He describes such conditions as " axeny" inhospitality. This point of view is also more appropriate when the inheritance of other factors affecting the symbiosis is considered specially in the determination of the number of infections which occur on the roots of susceptible plants ; differing degrees of hospitality rather susceptibility being shown. Bacterial virulence is probably not involved; nodule formation seems to be determined largely by host factors (Nutman, I948, I949). Recent work with Medicago sp. (Aughtry, 1948) shows that heritable factors are also concerned in cross-inoculation group specificity.

On the physiological plane the unusual mode of inheritance is of additional interest. If resistance is due to a cytoplasmic material whose production is under nuclear control, it must be able to reach to the cell wall of the root hair so as to be able to prevent penetration by the bacteria. Grafting experiments have shown that there is no transfer from root to shoot of substance affecting the infection or vice versa so that the hypothetical substance must be very local in its movement. This is not surprising in view of the very specialised route of infection normally taken.

Resistance to infection may be due either to the presence of a substance conferring immunity, or to the absence of a substance necessary for infection. On the first supposition, the existence of more than one gene for resistance would suggest the formation of 
different substances conferring resistance rather than the production of a single substance by different genetically determined biochemical routes. On the second supposition the different resistance genes may operate by blocking different stages in a chain of biochemical reactions leading to the production of the substance necessary to infection.

In connection with the spread of the nodulating habit in the Leguminose (or of resistance to infection with a restricted group) a cytoplasmic mode of inheritance controlling infection is of obvious significance especially if it was originally transmissible by infection in nature, i.e. by a virus.

These speculations may be useful in suggesting modes of approach to the problems of nodule formation, and closer study of the resistant plants themselves may lead to a better understanding of infection.

\section{SUMMARY}

I. An hereditary resistance in red clover to infection by nodule bacteria is described. Resistant plants are generally less vigorous than susceptibles, more chlorotic and hairier and show floral abnormalities. Root hairs of resistant plants show the characteristic curling in the presence of nodule bacteria but are not penetrated. On grafting no transference of resistance or susceptibility occurs.

2. Resistance is inherited as a simple recessive $(r)$ which acts in conjunction with a maternally transmitted component (specific cytoplasm $\rho$ ).

3. Maternal inheritance occurs only in certain crosses of resistant female plants with unrelated susceptibles (i.e. in outcrosses). Such crosses yield in some families $(a)$ wholly susceptible progeny, and in other families $(b)$ mixed progeny; the reciprocal families being wholly susceptible. The proportion of resistant segregates of $(b)$ approach 50 per cent. in the original outcross and decrease with each succeeding outcross generation. Unrelated susceptibles of types (a) or (b) breed true.

4. A partial elimination of resistant plants occurs in mixed families with an intercalary susceptible generation between the susceptible parent and a resistant ancestor which is accounted for as due to zygotic and post-zygotic lethals. This elimination is assumed to be due to the dilution of the cytoplasmic factor.

5. Resistant plants breed true except in some of the families which derive from more than a single known susceptible outcross ancestor. In such families a variable proportion (up to 50 per cent.) of susceptibles appear ; breeding experiments suggest that supplementary factors are concerned.

6. Resistance is assumed to be due to a cytoplasmically located substance the production of which is conditioned by the recessive factor $r$. In the absence of this substance in the developing embryosac, $r r$ zygotes are normally lethal; it is thus an essential metabolite 
and without some of it already being present it cannot be produced by $r$.

7. The recessive resistance gene $(r)$ is not linked with the sterility alleles $(S)$, and is inherited independently of factors determining primary nodulating habit (earliness or lateness), the number of nodules formed, or a recessive factor $(i)$ for ineffectiveness in nitrogen fixation.

8. Simply inherited morphological abnormalities are not more frequent among the resistant lines and derivatives than in unselected material. The following six simple recessives were identified :albino $(w)$, blue-green dwarf $(b g d)$, crimped leaf $(c l)$, raspberry head $(r h)$, pink flush $(p f)$ and stump root $(s r)$.

9. Certain genetically indeterminate abnormalities (especially dwarfing, chlorosis and abnormal germination) are more frequent in resistant $q \times$ susceptible than in the reciprocal crosses independently of the segregation of resistant plants. Similar reciprocal differences also occur sporadically in the wild population at a frequency equal to that in the combined outcrosses of resistant female plants and reciprocals, suggesting a similar mode of inheritance. Elsewhere in the experimental stocks such abnormalities occur with the same frequency as in a comparatively inbred wild population.

Acknowledgments.-The author is indebted to Dr Watkin Williams, Professor K. Mather, F.R.S., Dr H. Kalmus, Dr V. Philip and Dr A. G. Fabergé for discussion and criticism during the course of the work and to Miss Mabel Dunkley, Joan Grawley and Mary Williams for technical assistance. Special thanks are also due to Dr H. G. Thornton, F.R.S. and Dr G. D. Darlington, F.R.S. for advice and help in the preparation of the material for publication.

\section{REFERENCES}

AUGHTRY, J. D. 1948 .

Effect of genetic factors in Medicago on symbiosis with Rhizobium. Cornell Univ. Agric. Expt. Sta. Mem., 280, 18 pp.

BATESON, W., AND GAIRDNER, A. E. I92 I.

Male sterility in flax.

7. Genet., II, 269-275.

CHEN, H. K. 1938.

The production of growth substances by clover nodule bacteria.

Nature, I42, 753 .

Chittenden, R. J., AND PELlew, C. 1927.

A suggested interpretation of certain cases of Anisogeny.

Nature, II9, I0-1 I.

FRED, E. B., BALDWIN, I. L., AND MCCOY, E. 1932.

Root nodule bacteria and leguminous plants.

Univ. Wis. Madison, U.S.A.

GAUMANN, E. 1946.

Pflanzliche Infektionslehre, Birkhäuser, Basle, 6 I I pp. 
HARLAN, H. V., AND POPE, M. N. 1922.

The germination of barley seeds harvested at different stages of growth.

J. Hered., 13, 72-75.

KEILIN, D., AND WANG, Y. L. 1945 .

Hæmoglobin in the root nodules of leguminous plants.

Nature, 155, 227.

KENDAL, M. G. 1947.

The advanced theory of statistics. Vol. I. Griffin, London.

KLEGZKoWSKA, J., NUTMAN, P. S., AND BOND, G. 1944 .

A note on the ability of certain strains of Rhizobium from peas and clover to infect each other's host plants.

7. Bact., $48,673-675$.

KLECZKOWSKI, A., AND THORNTON, H. G. 1944 .

A serological study of root nodule bacteria from pea and clover inoculation groups.

J. Bact., 48,66 I -672 .

LINDEGREN, G. C. 1945 .

Mendelian and cytoplasmic inheritance in yeasts.

Ann. Miss. Bot. Gard., 32, 107-123.

MCCOY, E. 1932.

Infection by Bact. Radicicola in relation to the microchemistry of the host's cell walls. P.R.S., B., I10, 5I4-533.

MICHAELIS, P. 1937.

Untersuchungen zum problem der Plasmavererbung.

Protoplasma, 27, 284-289.

NUTMAN, P. S. I 94 I.

Studies in vernalisation of cereals. VII. A study of the conditions of formation and the subsequent growth of dwarf embryos of rye.

Ann. Bot. N.j., 5, 353-374.

NUTMAN, P. S. $\quad$ I946.

Genetical factors concerned in the symbiosis of clover and nodule bacteria.

Nature, I57, 463-465.

NUTMAN, P. s. $194^{8}$.

Physiological studies on nodule formation. I. The relation between nodulation and lateral root formation in red clover.

Ann. Bot. N.S., I2, 8 I-96.

NUTMAN, P. S. $\quad$ I949.

Physiological studies on nodule formation. II. The influence of delayed inoculation on the rate of nodulation.

Ann. Bot. N.S. (in press).

RHOADES, M. M. I943.

Genic induction of an inherited cytoplasmic difference.

P.N.A.S., 29, 327-329.

SABET, Y. S. 1946.

Bacterial root nodules in the Zygophyllaceæ.

Nature, ${ }_{157}, 656$.

SIRKS, M. J. I93I.

Plasmatic influences upon the inheritance of Vicia Faba. I, II and III.

Proc. Kon. Ak. Wet. Amsterdam, 34, 1057-1062, Io64-I I 72, 1340-1346. 
SONNEBORN, T. M. $\quad$ I 946.

Experimental control of the concentration of cytoplasmic genetic factors in Paramecium.

Cold Spring Harbor Symp. Quant. Biol., II, 236-255.

THORNTON, H. G. 1930.

The early development of the root nodule of lucerne (Medicago sativa, L.).

Ann. Bot., 44, 385.

WETTSTEIN, FRITZ VON. 1928.

Morphologie und Physiologie des Formwechsels der Moose auf genetischer Grundlage.

Bibl. Genet., ro, I-2 16.

WILLIAMS, R. D. 1925 .

Studies concerning the pollination fertilisation and breeding of red clover.

Bull. N. 4. Welsh Plant Br. St. Aberystwyth. $5^{8} \mathrm{pp}$.

WILLIAMS, R. D. 1939 .

Genetics of chlorophyll deficiencies.

7. Genet., 37, 441-482.

WILSON, J. K. 1939 .

Leguminous plants and their associated organisms.

Cornell Univ. Agric. Expt. Sta. Mem., $221,4^{8}$ pp.

WINGE, Ö., AND LAUSTEN, o. I940.

Cytoplasmic inheritance in yeast.

C.R. Lab. Carlsberg Serie Physiol., 23, I 7-59.

VIRTANEN, A. I. $\quad$ I 945.

Symbiotic nitrogen fixation.

Nature, 155, 747 . 

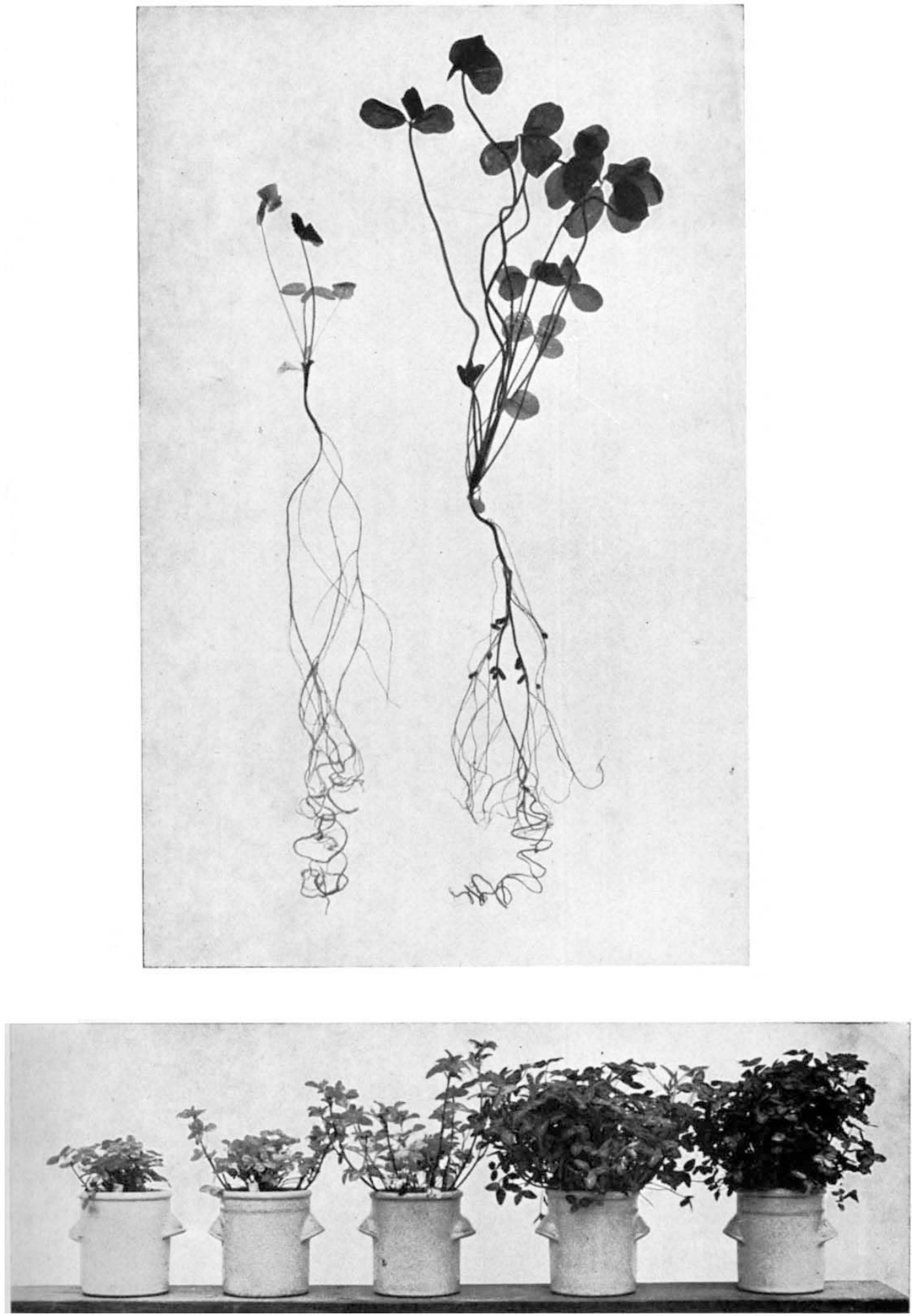

(a) Resistant and susceptible clover plants from an agar culture $\left(X^{\prime}\right)$. (b) Three resistant plants (on Jeft) and two susceptible heterozygous plants grown in soil with added nitrogen fertiliser. 
Plate II.-Grafts of resistant and susceptible clover plants

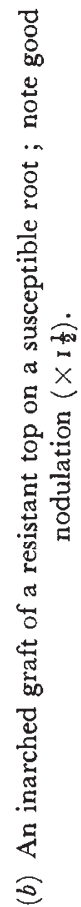

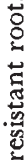

$$
\begin{aligned}
& \text { 응 } \\
& \text { 옹 }
\end{aligned}
$$

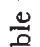

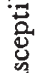

$$
\begin{aligned}
& \text { ज } \\
& \text { 号 }
\end{aligned}
$$

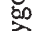

$$
\begin{aligned}
& \text { 잉 } \\
& \text { 密 } \\
& \text { 范 } \\
& \text { 푱 } \\
& \text { 参 } \\
& \text { s }
\end{aligned}
$$



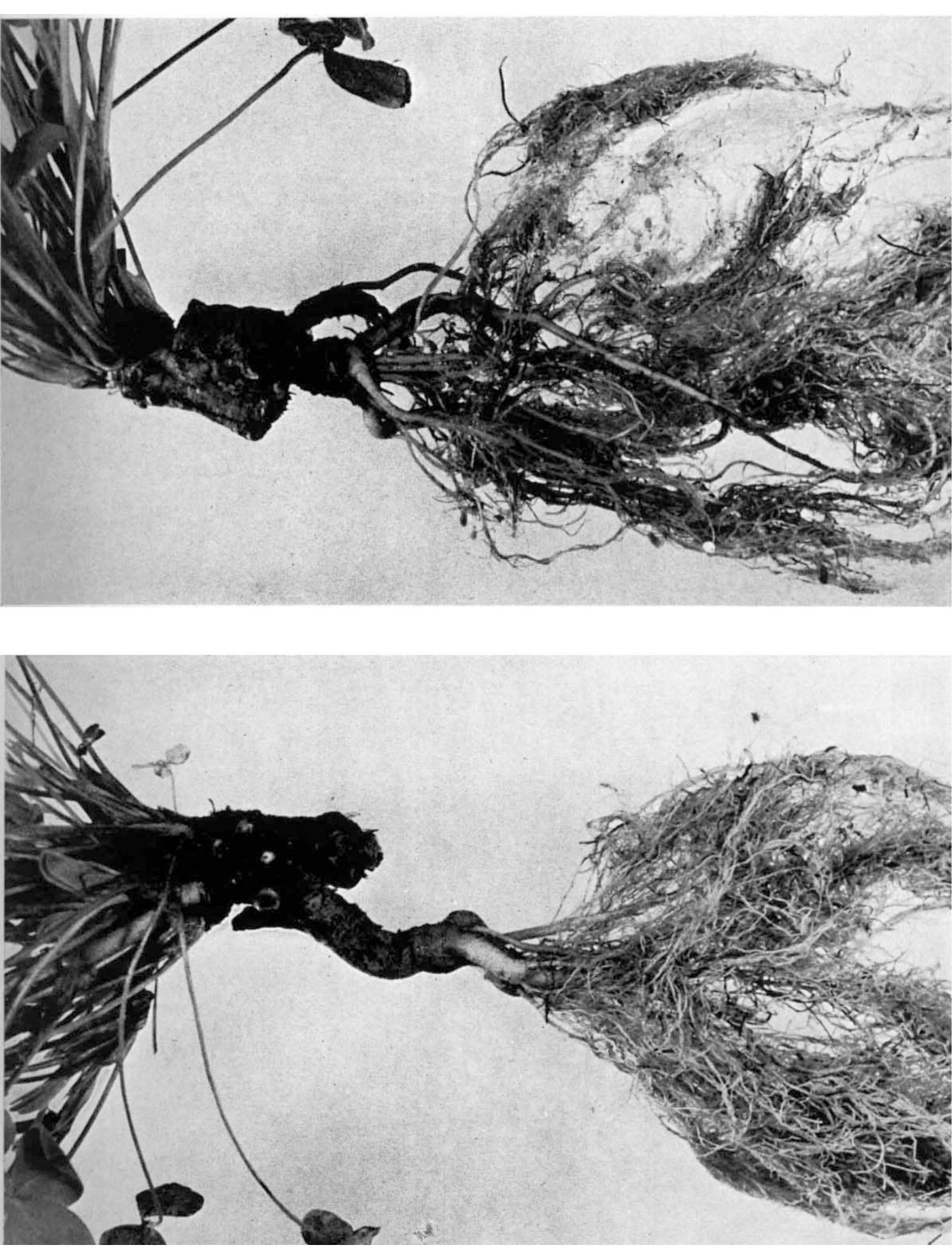
Plate III.-Simple recessives

(a) "Raspberry head," an inflorescence abnormality $\left(\times 2 \frac{1}{2}\right)$. (b) A "blue-green dwarf" plant, nine months old, growing in soil $(\times 4)$. (d) Normal and "stump-rooted" plants from an agar culture $\left(X_{I}\right)$. (c) Resistant and susceptible blue-green dwarfs from an agar culture $\left(x_{1}\right)$. 
